\title{
THE IMPACT OF THE INTEGRATION OF COOPERATION WITH THE EUROPEAN UNION ON THE DEVELOPMENT OF THE AGRARIAN SECTOR OF UKRAINE
}

\section{Markova Ievgeniia ${ }^{1}$ \\ Shestakovska Tatyana ${ }^{2}$}

DOI: http://dx.doi.org/10.30525/978-9934-571-28-2_19

\begin{abstract}
The article examines the trends and prospects of the development of relations between Ukraine and the EU with using modern assessment methods. It outlines the geopolitical priorities of Ukraine's integration strategy, determines the legal aspects of relations between Ukraine and the EU, analyses the main directions of cooperation between Ukraine and the EU. The state of modern Ukrainian European integration policy is investigated, too. The article substantiates the peculiarities of the development of the agrarian sector of the economy in the context of integration into the EU, which confirms that the modern global society is undergoing transformational processes, in which Ukraine must take and takes part. The current problems of national integration strategies in the context of the main aspects of the modern EU are also analyses. The study of the positive experience of the EU countries regarding the use of raw materials for energy agricultural resources and the awareness of the objective need for finding alternative kinds of fuels and energy for Ukraine has given rise to the need to develop a bioenergy industry, which, in its turn will allow the introduction of an environmental ideology in the field of the production and consumption of bioenergy. The methodological approaches are determined, the theoretical conclusions are obtained which can be used in the process of development of the strategy of agricultural development of Ukraine in the conditions of European choice while preserving its own identity. The use of an econometric method for predicting the effectiveness of the integration of cooperation between the EU and Ukraine is offered. The theoretical effects of Ukraine's integration with the EU and the possibility of their implementation in practice are determined as well.
\end{abstract}

\footnotetext{
${ }^{1}$ Doctor of Economics,

Kherson F.F. Ushakov Maritime Institute of Postgraduate Education, Ukraine

${ }^{2}$ Candidate of Economic Sciences, Senior Lecturer,

Chernihiv National Technological University, Ukraine
} 


\section{Introduction}

A characteristic feature of the modern world development of the countries is increasing of integration processes in the world and Europe in particular. However, even those countries that are not the part of the integration associations inevitably feel y their considerable influence. Following the last enlargement of the EU Ukraine has become a direct neighbor of the European Union. This opens up new opportunities for extending cooperation between Ukraine and the EU.

The question of the integration of choice was an important part of the national development strategies of Ukraine since the very beginning of the country's existence as a sovereign state. Geopolitically Ukraine is located between large integration associations: the European Union (EU) in the west and the associations of the countries of the former Soviet Union in the east, the most important of which are the Eurasian Economic Union (YEAES) and the Commonwealth of the Independent States (CIS). Ukraine's relations with these associations have expanded so far. For a long time promoting Ukraine's cooperation with the EU was seen as a major development strategy as the integration within the CIS had proceeded slowly through a complex restructuring of the economies of member countries of the association. The study of the influence of extending integration with the EU on the economy is important for working out the strategy of development of Ukraine. The issue is complicated by the fact that since 2013 Ukraine has been going through a deep economic crisis that significantly affected the change of starting positions of the country entering a deep and comprehensive free trade area with the EU. The signing of the Association Agreement actually became an important event in bilateral relations between Ukraine and the EU.

The development of integration at the European level is a modern sign of progressive changes in the agrarian sector and a relatively new direction in the research of the national agrarian science. The European landmarks provide the agrarian sector with an appropriate vector of development and open up new opportunities for the revival of agriculture, create additional comparative advantages in the agro-food market in the conditions of globalization of the economy. In order to successfully solve the problems of European integration, the agrarian sector of Ukraine's economy has sufficient prerequisites: a rich natural resource and export potential, a significant human capital, a gradually growing investment attractiveness, a preserved pattern of rural life and centuries-old traditions of agriculture. Consequently, 
the level of readiness of the domestic agrarian sector of the economy to the conditions of European integration, as compared to the countries which joined the EU in the last wave of expansion, testifies that similar transformational changes in our country did not take place, which has caused the urgency of this article [1-2].

Setting objectives. The determination of the directions of transformation of the state policy in the conditions of European integration in the context of ensuring the ecological safety of the agrarian sector of the national economy.

\section{The main directions of economic cooperation between Ukraine and the EU in the framework of the Association Agreement}

Since 01/01/2016 p. the Association Agreement of Ukraine has come into force with the EU, which is conditionally divided into two parts - political and economic. It is the economic part of the agreement that is worked out in detail and proven as the most important in the extending of the integration of cooperation between Ukraine and the EU because it is designed to give Ukrainian economy new opportunities for growth and development.

It should be emphasized again that the integration between Ukraine and the EU is formed according to the model of asymmetrically deep and comprehensive free trade area. Accordingly, from the author's point of view, all the changes that have to take place by the virtue of the Agreement can be divided into five key areas:

1) the formation of a free trade area;

2) the expansion of the trade area in services;

3) the regulation of the trade with intellectual property rights;

4) the regulation of trade with energy and cooperation in the energy sector;

5) the harmonization of the legislation of Ukraine in accordance with the EU regulations [3].

One of the major results of fulfilling the Agreement should be the abolition of import duties, which will theoretically allow Ukrainian goods to enter the European markets on more favorable terms. This will also have to promote and consolidate the application of the national treatment. However, taking into account the main articles of the Ukrainian export to the EU, significant opportunities for expanding its presence in the European markets will not arise in Ukraine.

For a variety of the agricultural products "import quotas", or size limits admissions are set by the EU. According to experts, these quotas subject to 
no more than $10 \%$ of Ukrainian corn export, $25 \%$ of confectionery, juices $40 \%, 50 \%$ wheat, etc subject under these quotas. To the extent protected in the EU there are 40 headings, whereas there are only three in the whole Ukraine - pork, poultry and sugar. So, not physical amounts of exports but the profits of some Ukrainian agricultural exporters will potentially increase. As for the Ukrainian commodity exports (ore, coal, wood, etc.), at the time of signing the Agreement, import duties on most of these headings were not applied. This refers to the metallurgical industry production [4-5].

Mutual cooperation in the energy sector between the EU and Ukraine includes a number of areas, as reflected in Article 338 of the Treaty. The most important, from the author's point of view, are as follows:

1) "modernization and gradual integration of the electricity system of Ukraine to the European electricity grid, creating a new energy infrastructure in order to diversify energy suppliers";

2) "conducting reforms based on the EU rules and standards for the development of competitive, transparent and non-discriminatory energy markets";

3) "promoting energy efficiency and conservation in line with the EU standards";

4) "revitalization and strengthening of the long-term stability and security of trade in energy goods, their exploration, extraction, purification, production, storage, transit, transmission, distribution and marketing";

5) "promoting mutual investment to the energy sector and establishing attractive stable investment climate";

6) "the development and support of renewable energy";

7) "Scientific and technical cooperation and the exchange of information for the development of technologies in the field of energy production, its transportation and end use."

Thus, in the future Ukraine is expected to do important work in changing laws and making reforms that will have to bring the energy sector to European standards.

One of the major potential benefits for Ukraine may become the possibility of solving the problem of extremely high physical and moral depreciation of fixed assets, gas transportation system (GTS). According to 2009 more than $70 \%$ of the total length of gas pipelines and about $80 \%$ of gas pumping compressor stations worked more than 20 years, the technical conditions of most storage facilities did not satisfy the requirements for 
their operation $85 \%$ of the basic equipment, $62 \%$ of wells and $84 \%$ of special hardware at the moment of state inventory worked for half its life. This is displayed in the low efficiency of the GTS, large current transmission losses and high probability of accidents during operation.

One of the most expensive destinations for Ukraine, most likely, will be the harmonization of national legislation of the country in accordance with the EU norms. The most important is the introduction of the European technical standards as national (Section 4, Chapter 3, Article 56) and the maximum approximation of the laws of Sanitary and Phytosanitary Measures (Section 4, Chapter 4, Article 64). However, the Agreement framework also stated the approximation of legislation in other areas public procurement (Section 4, Chapter 8, Article 153), competition (Section 4, Chapter 10, Article 256), statistical calculation (Section 5, Chapter 5, Article 356), environmental protection (section 5, chapter 6, article 363 ), transport (section 5, chapter 7, article 368), electronic communication (section 5, chapter 14, article 394), consumer rights protection (section 5, chapter 20, article 417) [6].

It was the introduction of European technical standards as national ones causing the greatest concern to domestic producers. The country operates many businesses that do not work on exporting and supplying its products exclusively to the domestic market. However, with the beginning of action of the European standards all producers, without exception, will have to either put them into production, or exit the business in connection with the incompatibility of their products to necessary quality indicators.

Since 11.01.2014 Ukrainian goods were given preferential access to European markets. The main advantage of partial entry of the agreement into force for Ukraine was receiving trade preferences on the EU markets (canceled almost $95 \%$ of tariffs on the EU goods in industrial production and $80 \%$ - for agricultural products) while maintaining its duties on European goods. However, the expected growth of Ukraine's exports to the EU did not happen.

Due to the unfavorable economic and political situation in Ukraine during 2014-2015 years granting trade preferences with the EU has not made a positive impact on Ukrainian exports. If in 2014 as a whole, its volume increased by $1.5 \%$ and 16 countries out of 28 , showed positive trend in 2015 this dynamic was shown by only three countries: Slovenia (slight 1.8\%), Denmark (15\%) and Malta (655.6\%), which characterizes 
not so much a real deepening of trade relations between the countries but unprecedented intensification of Ukrainian business in terms of the use of offshore schemes. On average, in individual countries falling exports from Ukraine amounted to $20-30 \%$, and a total export to the EU countries in 2015 decreased by $23.3 \%$. In the short term Ukraine will certainly expect problems with the whole set of adverse effects, and to receive any benefits in the long run requires the development of methods of forecasting assess of the effectiveness of the Agreement, taking into account the current state of the economy and significant financial problems in Ukraine [3].

The evaluation of the main political, economic, social, environmental, scientific and technical and educational and professional factors of the model of European integration, whose analysis gives reasons to consider the integration process in the agricultural sector of the economy not as a one-time change in the quality of socio-economic environment, but as a complex and permanent process, directed to macroeconomic stabilization, creation of a favorable investment climate, development of competition, the improvement of labor quality, the diversification of rural economy of the price equilibrium of the agrarian market and stable funding [2].

The purpose of the agrarian European integration is to combine the agrarian potentials of the member states (first of all, their agrarian markets and economic actors) with the subsequent modernization of agriculture and ensuring economic efficiency through mutual responsibility for the final results at all stages of agrarian cooperation and mutual interest of all participants of the integration process in a high level of food security of the countries-members of the association.

The folliwing basic principles of the process of European integration in the agrarian sector, are allocated: 1) the food security and sustainability of development; 2) efficiency and competitiveness; 3) the unity of purposeful and valuable rationality of the behavior of participants used by the countries-integrators in view of the existing natural-biological and socio-economic conditions of the functioning of the agricultural sector [7-8].

The modern principles of European integration in the agrarian sector of the economy represent an organic system and add certainty as for ensuring the sustainability of its development, allow to solve specific problems of the industry for a certain period of time, promote the creation of competitive environment, taking into account the interconnection of exogenous and endogenous factors. 


\section{Markova levgeniia, Shestakovska Tatyana}

Joining the EU gives the opportunity to use the communitarian mechanism for solving the problems of agricultural development, creates the necessary conditions for increasing the effect of integration measures and stimulates economic growth. But it would be wrong to assert that the benefits of integration are immediate and are obtained automatically by all countries without exception. Summarizing the main achievements and losses of the CEE countries as a result of the influence of the EUSAP on them, made it possible to highlight the most important steps towards European integration for Ukraine's agriculture. No matter how controversial was the experience of the countries of the last two waves of EU enlargement, the differences and problems in the development of the domestic agricultural sector are no more than in each separate country of this association.

The harmonization of the standards of the quality and safety of agricultural products with the requirements of the COP and the EU legislation is necessary. Harmonized standards for a domestic agricultural commodity producer are the only way to withstand the competition in the foreign market. The conducted studies indicate a low level of management system the quality of agro-food products and make it possible to reveal the main reasons for such a situation. The most important are the following: the existence of technical barriers; the uncertainty of approaches to strategic management of the system of managing the quality and the provision of appropriate methods for improving the safety of agri-food products.

The solution of the above mentioned problems is complicated due to the functioning of a complex, non-transparent, three-level standardization system in Ukraine. In order to have concrete bases for their implementation, integration and coordination of actions of all stakeholders involved in this process, strengthening of state supervision and control throughout the food chain; environmentalization of agrarian production are necessary. Ignoring the ecological factor in the agrarian reforms in Ukraine has led to a violation of the parity of economic, social and environmental interests that underlie the strategy of sustainable development. Compared to the EU, ecological agriculture has not been properly promoted in our country [9-10].

It is necessary to form the system of ecological agriculture in the medium term, which should meet the needs of the domestic market, taking into account the features of the European model of environmentalization of the industry. Since the organic production is not profitable and it is necessary 
to use high-value marketing measures for its development and support, we assume that in the short-term prospects, the traditional importers of organic products will take the leading position in the market.

The development of overseas markets for environmentally friendly products is a real but long-term prospect for Ukraine. First of all, the system of public administration in this area should promote the development of the ecological direction in agriculture through the support of scientific development, harmonization of standards, development of technological and organizational regulations, as well as the state programs of ecologization with the provision of financial support. As a long-term perspective, taking into account the peculiarities of the European agrarian model, the strategy of ecologization of agrarian production is proposed; the formation and development of bioenergy markets.

\section{Results and discussion}

The results of cooperation between Ukraine and the EU in the framework of the Association Agreement, first of all, should reflect the volume of foreign trade of Ukrainian goods. To assess these potential changes we will build the appropriate gravity model. The advantage of using this econometric method in this case is the inclusion in the model dummy variable to assess the impact on exports and imports of the presence or absence of preferences in trade relations of the country with its major partners.

The model of J. Tinbergen proposed in 1962, is considered a classic one and is as follows:

$$
\mathrm{E}_{\mathrm{ij}}=\alpha_{0} \operatorname{GDP}_{\mathrm{i}}^{\alpha 1} \mathrm{GDP}_{\mathrm{j}}^{\alpha 2} \mathrm{DIS}_{\mathrm{ij}}^{\alpha 3},
$$

where Eij - the volume of exports from country $i$ to country $j$, money units; $\alpha 0$ - free term, constant;

GDPi - GDP i, money units;

$\alpha 1, \alpha 2, \alpha 3$ - indicators that show that factors and productive feature need not be directly proportional;

GDPj - GDP $\mathrm{j}$, money units;

DISij - the distance between country $i$ and country $j, \mathrm{~km}$.

The model of X. Linneman has a more general view, as it is assumed that the trade is influenced by not only GDP and the distance between them, but a number of other factors that can be expressed either numerically or by entering the model dummies. So we applied later model expressed by (2): 


$$
E_{i j}=\alpha_{0} \operatorname{GDP}_{i}^{\alpha 1} \operatorname{GDP}_{j}^{\alpha 2} \mathrm{POP}_{\mathrm{i}}^{\alpha 3} \mathrm{POP}_{\mathrm{j}}^{\alpha 4} \mathrm{DIS}_{\mathrm{ij}}{ }^{\alpha 5} \mathrm{PREF}_{\mathrm{ij}}^{\alpha 6} \text {, }
$$

where POPi - the population of the country i, people.;

POPj - the population of the country $j$, people.;

PREFij - trade preferences between countries; if there are no Preferences, PREFij $=0$ if there are preferences, then PREFij $=1$

According to common practice, for ease of calculation we transform formula (2) to form a multiplicative additive through logarithms:

$$
\begin{gathered}
\ln E_{\mathrm{ij}}=\ln \alpha_{0}+\alpha_{1} \operatorname{lnGDP}_{\mathrm{i}}+\alpha_{2} \operatorname{lnGDP}_{\mathrm{j}}+ \\
+\alpha_{3} \operatorname{lnPOP}_{\mathrm{i}}+\alpha_{4} \operatorname{lnPOP}_{\mathrm{j}}+\alpha_{5} \operatorname{lnDIS}_{\mathrm{ij}}+\alpha_{6} \mathrm{PREF}_{\mathrm{ij}}
\end{gathered}
$$

Based on the formula (3), for the country i take Ukraine and build a gravity model $\operatorname{lnEij}$ of exports and imports lnIij. This we will take into account the following conditions:

1) the model includes data on $28 \mathrm{EU}$ countries (including data for Croatia for the entire study period), the countries of the free trade zone of the CIS, the countries, whose share in total exports / imports of Ukraine is on average less than $1 \%$. This geographical sample covers $83.2 \%$ of total exports and $88 \%$ of total imports in 2016 ;

2) the model is focused on Ukraine, that is the mutual trade flows of economic partners of Ukraine are not captured;

3) the observation period, 2009-2016 (8 years);

4) according to the conventional method, as an indicator of the distance between the countries, the distance in a straight line between the capitals of states is used;

5) the construction of models is made by a panel data with cross-platform software package for econometric analysis "Gretl".

The coefficient of determination of the model is $80 \%$. Thus, the mathematical description of gravity model export lnEij Ukraine is as follows:

$$
\begin{aligned}
& \operatorname{lnE}_{\mathrm{ij}}=-37,61+1,08 \operatorname{lnGDP} \mathrm{IP}_{\mathrm{i}}+8,21 \operatorname{lnPOP}_{\mathrm{i}}+ \\
& +0,24 \ln \text { POP }_{\mathrm{j}}-1,49 \ln \operatorname{liS}_{\mathrm{ij}}+0,52 \mathrm{PREF}_{\mathrm{ij}}
\end{aligned}
$$

Testing the constructed model for heteroskedasticity has also revealed its presence. Let us construct a model LnIij adjusted for heteroskedasticity.

The coefficient of determination of the model is $86 \%$. Thus, the mathematical description of gravity model of import lnIij Ukraine is as follows:

$$
\begin{gathered}
\operatorname{lnI}_{\mathrm{ij}}=-30,45+1,21 \operatorname{lnGDP} \mathrm{P}_{\mathrm{i}}+0,63 \operatorname{lnGDP} \mathrm{j}_{\mathrm{j}}+ \\
+6,17 \operatorname{lnPOP}_{\mathrm{i}}+0,33 \ln \mathrm{POP}_{\mathrm{j}}-1,42 \ln \ln _{\mathrm{ij}}++0,42 \mathrm{PREF}_{\mathrm{ij}} .
\end{gathered}
$$


Let us predict the volume of foreign trade of Ukraine for 2017 based on the following changes in the availability of preferential trade regimes:

1) the cancellation of preferences in bilateral trade between Ukraine and Russia;

2) the provision of European goods preferential conditions for access to the Ukrainian market.

Note that due to the high unpredictability of current trends adequate forecasting is possible only in the short term.

As a result of calculations based on the models built by the author of the models (4) and (5) of possible volumes of foreign trade of Ukraine with selected countries in 2017 the following predictions were received:

1) the drop in exports to the countries - the main partners, compared to 2016 will amount to $13.3 \%$ (from 31.7 billion. US dollars to 27.5 billion US dollars);

2) the drop in imports from the countries - the main partners, compared to 2016 will amount to $8 \%$ (from 32.6 billion. US dollars to 30 billion US dollars);

3 ) the growth of exports to the EU compared to 2016 will be $2.8 \%$ (from 13 billion. US dollars to 13.4 billion US dollars);

4) the increase in imports from the EU compared to 2015 will amount to $30.4 \%$ (from 15.3 billion. US dollars to 20.1 billion US dollars);

5 ) the recovery of preferential trade conditions with Russia may increase the volume of Ukrainian exports to 2.1 billion US dollars (6.6\%), imports by 2.3 billion US dollars (1\%).

On the basis of the calculations several important findings can be made. First, as a whole in 2017 a further decline in the Ukrainian foreign trade (especially - exports) will be observed. Second, the growth of Ukraine's foreign trade with the EU countries (especially - imports) is predicted. Thirdly, the abolition of preferential regime in mutual trade between Ukraine and Russia will seriously affect the change in the total volume of foreign trade of Ukraine (especially - for export).

The possibilities for expansion of Ukraine's exports are limited. Unilateral preferences regime in relations between Ukraine and the EU has also acted in 2016, but the effect of the opening of European markets for Ukrainian goods, was fully offset by a huge drop in the economy of the country. So the primary task for the Ukrainian economy is to achieve the pre-crisis volume of exports, that can contribute to the mutual lifting of 


\section{Markova levgeniia, Shestakovska Tatyana}

trade barriers. In any case, we should not expect a significant increase in exports.

There is a theoretical threat of a sharp increase in imports associated with the opening of the national market for European producers. However, from a practical point of view it is unlikely to happen. The fact is that the gravitational model does not account for reducing the solvency of the Ukrainian population. Even if there is a significant increase in the number of products manufactured in Europe, due to the sharp devaluation of the currency the prices will significantly grow. The population of Ukraine, in its turn, does not have enough money to buy either expensive goods, or the goods of the middle class. According to the State Statistics Service of Ukraine, in $20159.4 \%$ of the population had income below the subsistence minimum. It should be noted that the growth rate of the subsistence minimum does not correspond the rate of growth of consumer price index. For example, in 2014 the living wage increased by 5.6\% against rise in prices of $12.1 \%$. In 2015 price increase as for 2014 was $48.7 \%$, while the cost of living for the year rose by only $13.1 \%$. This means that according to the results of 2015 the proportion of the population with low incomes significantly increased. Ultimately, in the short and medium term, European manufacturers will have little interest in such a broad increase in exports to Ukraine.

Cooperation between Ukraine and the EU is asymmetrical due to the fact that the partners differ not only in the size and level of economic development, but also in the role played by each other. Therefore, one should take into account that by theoretical implementation of the Association Agreement Ukraine should get relatively more advantages than the EU. The expected effects of the implementation of the Agreement and the author's evaluation of their feasibility in the current crisis are shown in Table 1.

One of the major trends of 2017-2019, will likely remain the decline in the volumes of industrial production. If in 2013 the share of industry in the economic structure of Ukraine comprised $29 \%$, then by 2015 it had dropped to $24.4 \%$. The violation of the production chain "coal-coke-metal" leads to a decline in production volumes in a leading steel industry. Existing enterprises experience the disruption in the supply of raw materials and export of manufactures. There has been a sharp decline in production in areas where cooperation has been developed, particularly in engineering. The production in the mining industry only during 2014 dropped by $35 \%$, and chemical - by $36 \%$. 
These negative trends occur due to the influence of a combination of factors that facilitate and hinder the development of industry in the country. On the one hand, there is a theoretical chance of carrying some European industries in Ukraine because of the relatively low cost of labor. On the other hand, as it was mentioned above, European manufacturers will have little interest in expanding production in the face of shrinking demand. In addition, there are high risks of the default investments.

Table 1

The theoretical effects of Ukraine's integration with the EU and the possibility of their implementation in practice

\begin{tabular}{|l|l|l|}
\hline $\begin{array}{c}\text { The theoretical } \\
\text { effect }\end{array}$ & $\begin{array}{l}\text { The expected realization } \\
\text { of The theoretical } \\
\text { effect in practice after } \\
\text { signing the Association } \\
\text { Agreement }\end{array}$ & $\begin{array}{c}\text { Author's assessment of the feasibility } \\
\text { of implementing the desired effect } \\
\text { in practice }\end{array}$ \\
\hline 1 & \multicolumn{1}{|c|}{2} & \multicolumn{1}{c|}{3} \\
\hline $\begin{array}{l}\text { The effect } \\
\text { of "trade } \\
\text { expansion" }\end{array}$ & $\begin{array}{l}\text { - expanding the range of } \\
\text { quality goods of the } \\
\text { European production on } \\
\text { the domestic market; } \\
\text { - an increase in exports } \\
\text { of goods and services in } \\
\text { the EU }\end{array}$ & $\begin{array}{l}\text { 1) A significant increase in imports is } \\
\text { unlikely of reasons: } \\
\text { - Reducing of the demand on the } \\
\text { domestic market; } \\
\text { - Reducing purchasing power; } \\
\text { - An increase in import prices due to the } \\
\text { devaluation of the national currency. }\end{array}$ \\
$\begin{array}{l}\text { 3) The imported products are likely to } \\
\text { be substituted by uncompetitive goods } \\
\text { domestic production. } \\
\text { 2) Failure to expanding trade } \\
\text { in manufacturing due to its low } \\
\text { competitiveness. } \\
\text { 3) Weak expand of agricultural trade due } \\
\text { to the existence of "import quotas". }\end{array}$ \\
\hline $\begin{array}{l}\text { The effect } \\
\text { of the } \\
\text { "revitalization } \\
\text { of investments" }\end{array}$ & $\begin{array}{l}\text { - the improvement of the } \\
\text { investment } \\
\text { climate, resulting in } \\
\text { the increase of the } \\
\text { volumes of foreign } \\
\text { Investment in the economy } \\
\text { of Ukraine }\end{array}$ & $\begin{array}{l}\text { 1) Thrent state of the investment } \\
\text { climate promotes the capital outflow } \\
\text { from Ukraine. } \\
\text { 2) The interest in investing in } \\
\text { Ukraine's economy is unlikely in other } \\
\text { countries. } \\
\text { 3) In the long run the European intensive } \\
\text { production may remove geographically } \\
\text { close to the Ukrainian mining enterprises, } \\
\text { however, it is difficult to estimate } \\
\text { the rationality of this redislocation. }\end{array}$ \\
\hline
\end{tabular}




\begin{tabular}{|c|c|c|}
\hline & & Ending of Table 1 \\
\hline 1 & 2 & 3 \\
\hline $\begin{array}{l}\text { The effect } \\
\text { of the "scale" }\end{array}$ & $\begin{array}{l}\text { - The abolition of customs } \\
\text { duties will } \\
\text { help to increase } \\
\text { the production volumes; } \\
\text { - The production costs } \\
\text { will } \\
\text { decrease due to the } \\
\text { "Effect of the scale" }\end{array}$ & $\begin{array}{l}\text { 1) The current state of crisis of the } \\
\text { industrial complex will not contribute to } \\
\text { significant expansion in output. } \\
\text { 2) A significant expansion of production } \\
\text { of goods of uncompetitive manufacturing } \\
\text { is unlikely due to low demand for them } \\
\text { in Europe. } \\
\text { 4) A significant expansion of agricultural } \\
\text { production is unlikely because of the } \\
\text { existence of "import quotas". }\end{array}$ \\
\hline $\begin{array}{l}\text { The effect } \\
\text { of the } \\
\text { "employment } \\
\text { growth" }\end{array}$ & $\begin{array}{l}\text { - the opening of } \\
\text { production } \\
\text { units on the territory of } \\
\text { Ukraine by European } \\
\text { companies; } \\
\text { - the recognition of the } \\
\text { Ukrainian diplomas and } \\
\text { qualifications in the EU; } \\
\text { - facilitating the migration } \\
\text { of Ukrainian citizens to } \\
\text { the EU. }\end{array}$ & $\begin{array}{l}\text { 1) It is difficult to predict how European } \\
\text { companies will be interested in } \\
\text { transferring their production to Ukraine } \\
\text { in the current economic crisis. } \\
\text { 2) The text of the Association Agreement } \\
\text { between Ukraine and the EU has no } \\
\text { direct links to facilitating migration } \\
\text { regime or recognition of Ukrainian } \\
\text { qualifications; there is the only reference } \\
\text { to the inclusion of these issues to } \\
\text { the agenda of the talks on further } \\
\text { cooperation. }\end{array}$ \\
\hline $\begin{array}{l}\text { The effect } \\
\text { of "increasing } \\
\text { productivity" }\end{array}$ & $\begin{array}{l}\text { upgrading and } \\
\text { modernization of national } \\
\text { production }\end{array}$ & $\begin{array}{l}\text { In the current crisis conditions the } \\
\text { Ukrainian companies are practically } \\
\text { deprived of the financial capacity } \\
\text { of upgrading and modernization of } \\
\text { production. }\end{array}$ \\
\hline $\begin{array}{l}\text { The effect } \\
\text { of "increasing } \\
\text { income" }\end{array}$ & $\begin{array}{l}\text { 1) Lower prices for the } \\
\text { products by European } \\
\text { production. } \\
\text { 2) Increasing incomes of } \\
\text { the population through the } \\
\text { realization of the effect of } \\
\text { "increasing employment". }\end{array}$ & $\begin{array}{l}\text { Reduced incomes of the population due } \\
\text { to the devaluation of the currency, the } \\
\text { rising of prices and utility tariffs. }\end{array}$ \\
\hline
\end{tabular}

There are other factors as well. Ukrainian producers will have to switch to European standards of production quality, and it requires considerable financial costs. Most businesses need to spend almost complete modernization of the production process and train the staffs to work with new technologies. The Agreement empowers enterprises potentially to access to European credits, but many manufacturers are on the verge of bankruptcy and, accordingly, are high risk, so they are unlikely to qualify for all European 
credits, not to mention the impossibility of obtaining any credit facilities. There is a tendency to increase the country's exports towards low trade processing. The EU is generally more interested in preserving raw orientation of Ukrainian exports.

Probably, in 2017-2019 the difficulties in attracting investments in Ukraine, both in the public and in the private sector will continue. The investors are not interested to invest in the country for several reasons: it is a high risk of loss of investment, high levels of corruption, unpredictable economic and political climate. Alongside with a decrease of investments in Ukraine's economy the outflow of domestic capital abroad is likely to continue.

We can't help mentioning negative social trends. The continued deterioration of Ukraine's economy will lead to higher unemployment, which in its turn will trigger a new round of emigration. Above 300 thousand of people emigrated to the EU in 2015, mainly in Poland, Czech Republic, Germany. On the whole, the likely volume of emigration will increase. Moreover, the tendency of transition of temporary labor migration, focused on returning to Ukraine in the constant migration is observed. Also a negative impact on the population, especially the young and able-bodied has holding of military actions.

The foregoing facts enable us to conclude that in the current conditions of Ukrainian economic reality, especially in the short term period a significant expansion of cooperation between Ukraine and the EU is unlikely to happen, despite the fact that the signed Agreement creates necessary conditions for this. The European integration course for Ukraine has no alternative, but on the way the country expects many difficulties, trials, disappointments, awareness of the need of a healthy national egoism and the prediction of the consequences of foreign policy and economic decisions and getting rid of the illusions of receiving significant foreign assistance and rapid resolution of external agents of our internal depth problems. The economic integration as a process of development of sustainable relationships and deepening the division of labor, as a form of convergence and strengthening of cooperation of national economies could provide the impetus for the development of productive forces and modification of production relations. However, the integration is not able to replace a healthy economic policy aimed at the development of the internal market and the accumulation of domestic savings, the increase of national competitiveness and intensification of 
investments and innovations, attracting long-term foreign investments and the formation of strong and effective national companies [10].

In the 'Doing Business 2016' rating, Ukraine ranks 83 out of 189 seats (Poland -25, Germany -15), rising 4 positions compared to 2015. The exports of Ukrainian agricultural products to the European Union increased by $\$ 68.2$ million in 2016 and amounted to $\$ 4.12$ billion. It is reported by the press service of the Ministry of Agrarian Policy and Food of Ukraine. It is noted that in 2015 the deliveries to the European Union amounted to $26,6 \%$ of all agrarian exports of the country. Mostly agricultural profucts were exported to the EU: Cereals (corn, wheat, barley) - 1279.5 million dollars; - Oil (sunflower, rapeseed, soya) - 1185 million dollars; - Seeds of oilseeds (flaxseeds or rape seeds, soybeans, sunflower seeds) - \$ 587.5 million; - Residues and wastes of the food industry (cakes and other solid wastes obtained during the extraction of oil, soybean oil, waste from starch production, sugar, beet pulp, etc.) - $\$ 439.2$ million.

In 2016-2017, the marketing year compared with the previous period Ukraine increased sugar exports by 33 times - up to 344 thousand tons [3]. The main products of the Ukrainian export to European countries last year were (on cost indicators): cereals, oil, oilseeds, fruits and nuts. Also, among Ukrainian consumers, Ukrainian honey, meat, confectionery and juices were in great demand last year. Today we see an increase in the Ukrainian agrarian exports due to an increase in the supply of commodity groups such as sunflower oil by $\$ 505$ million, sunflower seeds by $\$ 36.1$ million, sugar by $\$ 16.5$ million. The most interesting for us is a significant increase in exports "Niche" fresh or processed products. Such as, for example, preserved tomatoes - by $\$ 14.3$ million, or twice, fresh and chilled vegetables -4 times, cucumbers -2.7 times, fresh fruits -2.5 times, margarine products -9 times, cocoa paste and cocoa butter, as well as ice cream, which in 2015 did not come to the EU at all. For Ukraine, this means a tendency towards diversification of the commodity structure of exports, which is a positive aspect. The imports of the European products to Ukraine also increased in 2016 and amounted to $\$ 1904.5$ million. The main products of import were food products such as sauces, coffee, tea and others $\$ 233.6$ million, cocoa beans and chocolate $-\$ 113.7$ million, as well as cereals $-\$ 105.6$ million, etc [3-4].

The trade surplus of bilateral agricultural trade between Ukraine and the EU in 2016 amounted to over $\$ 2.3$ billion. The foreign trade turnover of 
agricultural products between Ukraine and the EU countries amounted to $\$ 6182.9$ million in 2016. The major trade partners with the largest share in trade are: Spain $-15,3 \%$, Poland $-14.3 \%$, the Netherlands $-14 \%$, Italy $12.6 \%$, Germany $-10.1 \%$, France $-8.4 \%$, Belgium $-3.2 \%$, Great Britain $3 \%$, Portugal $-2.7 \%$, Romania $-2.2 \%$, Greece $-2 \%$, Hungary $-1.96 \%$ [8].

Gradually, go away references to the past, mainly aimed at economic results and the implementation of scientific advances, innovative technologies without taking into account the priority of the development of environmental and social factors. According to many scholars, all signs of an ecological crisis are observed in Ukraine, which is already considered as a crisis of the philosophy of being, the crisis of spirituality. The environmental degradation is the consequence of not only anthropogenic pressure on it, but also the impoverishment of the morality of the society, short-sightedness as for the future conflicts of an established standard of living. In this view, the main directions of the science of agroecology are at the forefront of overcoming the environmental problems in the agrarian sector [11-12].

Agroecology in the current difficult ecological and economic conditions should define a strategy for the development of agrarian production, aimed at preserving and reproducing, first of all, soil, water and biological resources, protecting the natural environment and providing people with high-quality food products in the necessary quantity [13].

By defining agroecology as a comprehensive and interdisciplinary science, ignoring its biogeochemical component is becoming increasingly irrelevant. The biocentric strategy of agriculture, as a condition for the formation of a balanced nature, utilization requires a comprehensive study of the living matter of the agrosphere.

For the evaluation and forecasting of agroecological processes it is important to calculate the coefficients of biogenic and physico-chemical migration of nutritive chemical elements - the coefficients of their biogenic accumulation, concentration, the coefficients of water mobility. The scientific value of the State monitoring of the lands can increase tenfold if we pass from the administrative and agro-soil zoning to the natural-functional, as well as increase the non-parametric part of the agro-chemical passport of the field and the number of investigated chemical elements-biofilms. The methodology of biogeochemical zoning makes it possible to estimate and predict the consequences of the ecological danger of most chemical elements for living organisms and endemic diseases of the population and is a 


\section{Markova levgeniia, Shestakovska Tatyana}

significant criterion for shaping the territorial prospects for the development of food industry [14].

\section{Conclusions}

The need for developing an integration strategy for Ukraine was caused by the desire of our country to meet the requirements of modern global economic and political system as well as finding additional means to counter threats to international security. The specific geopolitical position and a long history of cooperation with European countries contribute to Ukraine's interest in active participation in integration processes in Europe. Thus, the European integration is officially declared the key priority of Ukraine's foreign policy. For Ukraine, European integration is the way of modernizing the economy, overcoming technological backwardness, attracting foreign investments and new technologies, creating new jobs, increasing competitiveness of domestic producers, access to world markets.

However, our study of the results of the Association Agreement between Ukraine and the EU leads us to the following conclusions. First, the stage for the growth of the Ukrainian economy and improvement of the living standards of its population are not created. Second, joining the Agreement in full force until it has improved economic conditions for Ukraine is not achieved. Thirdly stabilization and the settlement of internal political and military conflicts are essential for a favorable economic development of the country.

The political benefits of the integration of Ukraine into the EU are related to the creation of reliable mechanisms of political stability, democracy and security. Moreover, the EU membership will open the way for collective structures of common security of the European Union, ensure a more effective coordination with European countries in the field of export controls and non-proliferation of weapons of mass destruction, help to intensify cooperation in combating terrorism, organized crime, smuggling, illegal migration, drug trafficking and so on. The European choice of Ukraine opens new prospects for cooperation with the developed countries of the continent, providing opportunities for economic development, strengthening Ukraine's position in the global system of international relations. However, the success of any integration policy is not in the statements and declarations of the European choice, but in the banal pursuing the principles and objectives of this policy. The rapprochement with the EU is a guarantee, 
and the implementation of its requirements a tool for building democratic institutions in Ukraine.

The domestic agrarian policy needs to be interpreted from the standpoint of the triple approach, which is widely used in the EU member states and takes into account the importance of not only economic, but also social and ecological components of the national economy, meets the requirements of the EU and confirms the overwhelming influence on the efficiency of agrarian production of a balanced system of measures and means of the state influence in close connection with rural development, agro-ecological requirements, full protection of the rural population and be continued to explore. The implementation of the proposed socio-economic and environmental priorities will provide an opportunity for an adequate transition of the agrarian sector of the economy to the European agrarian model of development and will promote the competitiveness of agriculture in the medium and long-term perspective of eurointegration.

\section{References:}

1. Gryshova I. Yu., Mityay O.V. (2016) Competitiveness of agricultural enterprises as a key factor in sustainable development of agricultural sector. Ukrainian Journal of Applied Economics. Vol. 1, no. 2., pp. 25-35.

2. Markova Ie.Yu. (2016) Strategichne upravlinnya vy'robny'chogospodars 'koyu diyal'nistyu pidpry'yemstv ry'bogospodars'kogo kompleksu: problemy' teoriyi i prakty 'ky' 'The strategic management of the production and economic activity of enterprises of the fishing industry: the problems of theory and practice]. Kherson: Ayalant [in Ukrainian]

3. The official site of the Ministry of Economic Development and Trade of Ukraine [Electronic resource] - Access mode: http://www.me.gov.ua/ Documents/Detail?lang=en-UA\&id $=5867 \mathrm{bbb} 048-4922-\mathrm{a} 3 \mathrm{~b} 4 \mathrm{ff} 2 \mathrm{~d} 1 \mathrm{bb} 731 \mathrm{a} 6 \& \mathrm{title}=$ PokaznikiExportUkraine Za2016-Rik

4. Bighdan O.V. (2013) Naprjamy rozvytku ekologhoorijentovanogho aghrovyrobnyctva $\mathrm{v}$ mizhnarodnij praktyci [Areas of development of ecologically oriented agricultural production in international practice]. AgroSvit. Vol. 4. pp. 29-31.

5. Association Agreement between the European Union and its Member States, of the one part, and Ukraine, of the other part. Official Journal of the European Union. Available at:http://eeas.europa.eu/ukraine/docs/association_agreement_ ukraine_2014_en.pdf

6. Strielkowski W., \& Lisin E., \& Gryshova I. (2016) Climate Policy of the European Union: What to Expect from the Paris Agreement? Romanian journal of European affairs Vol. 16, no. 4, pp.87-90.

7. Gryshova I.Yu., \& Shestakovska T.L. (2017) The asymmetry of the resource configuration and its destructive impact on the capitalization of agribusiness. The 


\section{Markova levgeniia, Shestakovska Tatyana}

Scientific Papers of the Legislation Institute of the Verkhovna Rada of Ukraine, no. 2. pp. 128-133.

8. Gryshova I. Ju., \& Yanchuk A. O., \& Shestakovska T. L. (2017) The mechanism for implementing the functions of consumerism in market conditions. Scientific bulletin of Polissia, no. 1(9). pp. 93-101.

9. Sabluk P.T. (2007) Ekonomichnyj mekhanizm APK u rynkovij systemi ghospodarjuvannja [Economic mechanism of agroindustrial complex in the market economy system]. Economy of agroindustrial complex. no. 2. pp. 3-6.

10. Moghyljnyj O. M. (2014) Osoblyvosti derzhavnogho reghuljuvannja zajnjatosti v umovakh ekologhizaciji aghrarnogho vyrobnyctva [Features of state regulation of employment in conditions of ecologization of agrarian production]. Economy and the state. no. 6. pp. 6-12.

11. Gryshova I. Yu., Shestakovska T. L., Glushko O. V. (2017) The economic measurement of convergence of institutional impact on the sustainability of development. Scientific notes of the Institute of Legislation of the Verkhovna Rada of Ukraine, no. 4, pp. 75-80.

12. Nikoliuk O., Gryshova I., Shestakovska T. (2017). The organic production in the context of improving the ecological safety of production of the food industry. Food Science and Technology, Vol. 11, no. 4, pp. 103-111.

13. Markova Ie. (2017). Modern condition of agrarian sector of economy of Ukraine in conditions of implementation of public-private partnership. Economic forum. Lutsk national technical University, no.4, pp. 30-38.

14. Markova Ie. (2016). The Management of sustainable development of socioecological-economic system. Bulletin of Sumy national agrarian University. Series "Economy and management", Vol. 8, pp. 26-31. 